\title{
ABSTRACTS
}

This section of the JOURNAL is published in collaboration with the two abstracting Journals, ABSTRACTS OF World Medicine and Ophthalmic Literature, published by the British Medical Association. The abstracts are divided into the following sections: Syphilis, (General, Pathology, Therapy) ; Gonorrhoea (General, Pathology, Therapy); Chemotherapy; Other Venereal Disease Conditions; Public Health; Miscellaneous. After each subsection of abstracts follows a list of articles that have been noted but not abstracted. All subsections will not necessarily be represented in each issue.

\section{SYPHILIS (General)}

On the Significance of Growth in Roentgenological Skeletal Changes in Early Congenital Syphilis. ENGESET, A., EeK, S., and GilJe, O. (1953). Amer. J. Roentgenol., 69, 542. 10 figs, 30 refs.

From an examination of the radiographs and the history in 59 cases of infantile congenital syphilis at the University Hospital, Oslo, the authors conclude that the typical changes in the skeleton are due to growth disturbances rather than to the presence of active syphilitic tissue in the bones; further, that such changes are not synonymous with the presence of active syphilis. They point out that from the width of the zones of rarefaction and the position of the growth lines and newlyformed subepiphyseal normal spongiosa, the time of onset of the growth disturbance can be deduced and the duration of effective treatment of the mother determined. The periosteal changes are probably largely due to growth disturbances and secondary traumatic influences. These observations do not, however, apply in cases of late congenital syphilis. It is suggested that as the early bone lesions usually heal without leaving a scar or deformity, they are unlikely to be due to destructive inflammatory lesions. The authors state in conclusion that " while no irrefutable proof has been offered of the bone changes in infantile congenital syphilis consisting of syphilitic granulation tissue...the designations syphilitic endochondritis, diaphysitis, and periostitis should be abandoned in favour, for example, of osteochondroperiostitis ".

G. W. Csonka

Chorioretinitis of Congenital Syphilis. Klauder, J. V., and Meyer, G. P. (1953). Arch. Ophthal. (Chicago), 49, 139. 9 figs, bibl.

After a full review of the literature, the authors describe an investigation at the Wills Eye Hospital, Philadelphia, into the occurrence of chorioretinitis in patients with congenital syphilis. For this purpose they studied 223 cases of congenital syphilis with interstitial keratitis and also 71 cases of congenital syphilis without corneal involvement. The great majority of the 223 patients in the former group were between the ages of 8 and 25 years; in the latter group were 54 children without any ocular complaint, and seventeen patients (mostly adults) having some ocular involvement. Of the subjects with keratitis, thirty had signs of chorioretinitis and eighteen had perivascular sheathing. Of patients without keratitis, twelve had choroidal scarring and eight had perivasculitis.

According to the authors, the chorioretinal scarring did not fall easily into the four types described by SidlerHuguenin. The main feature was pigmentary disturbance, either granular or in annular zones. Changes resembling retinitis pigmentosa were found in three cases only, none of them associated with keratitis. Macular involvement occurred bilaterally in three and unilaterally in six of the 42 patients with chorioretinitis. The authors consider that the 26 cases with perivascular sheathing provided a large enough group to justify the recognition of this manifestation as a valuable diagnostic sign.

$$
\text { J. E. M. Ayoub }
$$

Observations on Anticomplementary Reactions. LIGHTER, A. G. (1953). Arch. Derm. Syph. (Chicago), 67, 362. 4 refs.

The author, working at a venereal disease clinic of the Los Angeles City Health Department, has investigated 144 cases in which an anticomplementary (AC) reaction was obtained in the complement-fixation test for syphilis. He classes such reactions as

(a) extrinsic, due to faulty technique in the collection of the specimen or execution of the test,

(b) intrinsic, where they are due to some property inherent in the serum.

All the reactions investigated were thought to belong to the latter group. In 137 cases the $\mathrm{AC}$ reaction was obtained with serum, in five with cerebrospinal fluid, and in two with both serum and cerebrospinal fluid; 127 of the patients were classed as syphilitic on grounds other than the complement-fixation test, nine as probably syphilitic, and eight as non-syphilitic.

No difference in sex or racial distribution was found between patients giving $\mathrm{AC}$ reactions and the general 
clinic population from which they were drawn, but a disproportionate number of the former were below 15 years of age. In the clinic population, 3.92 per cent. of patients with syphilis had congenital infections, whereas of the 127 syphilitic patients giving AC reactions, 33 (25.9 per cent.) had congenital syphilis.

An AC reaction was obtained on retesting after an interval of 2 weeks or longer in 57 cases ( 21 of congenital, 34 of acquired, and two of probable syphilis) ; in only one of the seven cases was a second $\mathrm{AC}$ reaction obtained with cerebrospinal fluid. The serum of 22 patients gave $\mathrm{AC}$ reactions twice, of seventeen three times, of seventeen from 4 to 8 times, and of one on no fewer than 21 occasions ; this last patient had primary syphilis. The observed incidence of repeatedly anticomplementary reactions among congenital syphilitics is almost ten times that to be expected if $\mathrm{AC}$ reactions were equally distributed among all stages of syphilis.

The author concludes that " because of the heavy participation of syphilis in general and of congenital syphilis in particular in the anticomplementary reactions, thorough examination and serological follow-up of persons with anticomplementary reactions should be made, especially of those with " repeatedly anticomplementary reactions ".

A. E. Wilkinson

Cortisone in Interstitial Syphilitic Keratitis. (Considérations sur l'action de la cortisone dans la kératitie interstitielle syphilitique.) Thomas, C., CoRDIER, J., and Algan, B. (1952). Bull. Soc. ophtal. franç., No. 4, 501. 7 refs.

The good visual and clinical effects of cortisone on interstitial syphilitic keratitis, lead the authors to think that the corneal manifestations of hereditary syphilis may be considered as a real adaptation disease. It is an allergy more than an infectious syndrome. J. Rougier

Pupil in Syphilis. Jaffe, N. S. (1953). Amer. J. Ophthal., 36, 493. 7 figs, 1 table, 13 refs.

The character, origin, and diagnostic significance of pupillary changes in neurosyphilis are discussed. Pupillometric evidence is offered in support of the view that intracranial involvement occurs early in syphilis.

H. E. Hobbs

Syphilitic Dacryoadenitis (In Czech). FENCL, F. (1953). Čsl. Ofthal., 9, 33. 2 figs.

Description of a case. The gummatous character of the infiltration was proved by microscopic examination of the excised gland.

M. Klima

Diagnostic and Therapeutic Problems and Possibilities in Certain Forms of Syphilis among other So-called Syphilitic Iridocyclitis. (In Dutch.) LuGT, L. VAN DER (1952). Ned. T. Geneesk., 96, 1504.

In a discussion of the difficulties in the diagnosis of syphilis in general the author stresses the special difficulties of diagnosis in iridocyclitis in which a syphilitic aetiology is suspected. As it is impossible to prove the presence of the micro-organism in the eye, iridocyclitis in a patient with sero-positive reactions which responds to antisyphilitic treatment is often regarded as syphilitic in origin. This diagnosis, however, should be accepted with reserve.

J. ten Doesschate

Reversibility of the Argyll Robertson Pupil in Tabes. (A reversibilidade do sinal pupilar de Argyll Robertson na tabes.) PINES, N. (1952). J. méd. Porto., 20, 105.

The author has observed some signs of reversibility of the Argyll Robertson pupil in three patients with tabes, treated by an original preparation of sodium iodide, magnesium thiosulphate, thiamine, and a local anaesthetic, administered intramuscularly. $H$. Moutinho

Anterior Internuclear Palsy of Syphilitic Origin. (Su di un caso di paralisi internucleare anteriore di origine luetica.) PisAnO, E. (1953). Boll. Oculist., 32, 242. 31 refs.

A Rare Symptom in Congenital Syphilis : Saucer-shaped Brown Opacity of the Lens. (Un symptôme cristallinien peu connu de la syphilis congénitale : la soucoupe brune supranucléaire postérieure.) FoRNI, S. (1953). Ophthalmologica (Basel), 125, 343. 3 refs.

Keratitis Parenchymatosa e Lue Congenita and Toxoplasmosis. Oksala, A. (1953). Acta ophthal. (Kbh.), 31, 187.

Third-Generation Syphilis. CAVER, C. V. (1953). Hawaii med. J., 12, 448.4 refs.

Third-Generation Syphilis. Report of a Probable Case. Wright, P. M., and Inoue, T. (1953). Pediatrics, 11, 465. 6 figs, 4 refs.

Thymus and Congenital Syphilis. (Thymus und konnatale Lues.) HöCKER, H. (1953). Hautarzt, 4, 378. 2 figs, 8 refs.

Infantile Cataract and Congenital Syphilis. (Cataracte infantile et syphilis congénitale.) GozBerK, R. A. (1953). Ann. Oculist.( Paris), 186, 141. 2 figs, 17 refs.

Diagnosis of Early Syphilis during Surveillance of Possible Contacts. (Le dépistage de la syphilis récente au cours de la surveillance des "contaminations possibles".) Pellegrin, J., Istria, and MAisonobe. (1953). Proph. sanit. morale, 25, 104. 1 ref.

Two Severe Forms of Congenital Syphilis : (1) Congenital Tabes. (2) Congenital Syphilis in the Second Generation. (Deux formes graves de syphilis héréditaire: 1, heredotabès-2, syphilis congénitale de $2^{\mathrm{e}}$ generation.) Pellegrin, J., and Guiberteau (1953). Proph. sanit. morale, 25, 99.1 ref.

Obstacles to eradicating Congenital Syphilis. WriGHT, J. J. (1952). Publ. Hlth Rep. (Wash.), 67, 1179. 1 fig., 11 refs. 
Aspects of Congenital Syphilis in Provence. (Aspects actuels de la syphilis congénitale dans la région provençale.) GiRAUd, P., and BERNARD, R. (1953). Pédiatrie, 8, 7 .

Maternal Syphilis as a Cause of Still Births and Neonatal Deaths. REDDY, J., and RATNAVATI, C. (1953). Indian J. med. Sci., 7, 91.5 figs, 14 refs.

Syphilis and Pregnancy. (Syphilis et grossesse.) DigonNeT, L., Bigey, L., and Payenneville, H. (1953). Presse méd., 61, 682.

Postnatal Preventive Treatment of Congenital Syphilis. (Die Praxis der postnatalen Präventivbehandlung der connatalen Lues.) Gumpesberger, G. (1953). Ost. $Z$. Kinderheilk., 9, 151. 45 refs.

Serial Radiological Observations in the Early Stages of Acquired Syphilis. (Röntgenologische Serienbeobachtung im Frühstadium der Lues acquisita.) BEUTEL, A. (1953). Radiol. clin. (Basel), 22, 228. 8 figs, 5 refs.

Risk of Syphilis Infection by Sexual Intercourse with Syphilitic Partner. SchäffER, G., and Sylvest, B. (1953). Acta derm-venereol. (Stockh.), 33, 91. 6 refs.

Selective Case-Finding in Syphilis Control. Moore, G., and Foster, M. T. (1953) Publ. Hlth Rep. (Wash.), 68, 167. 11 refs.

An Investigation into the Incidence of Syphilis among Illegal Immigrants by means of the Chediak Method. (Untersuchungen über das Vorkommen von Lues bei illegalen Grenzgängern mittels der ChediakMethode.) Alberts, M. (1953). Off. GesundhDiest, 14, 469 . 1 ref.

Social Pathology of Syphilis among the Bantu People of the Union of South Africa. SAX, S. (1953). S. Afr. med. J., 27, 129.24 refs.

Bantu Syphilis : Analysis and Observations on Therapy and Tests. SACHS, S. B., and Selesnick, H. (1953). S. Afr. med. J., 27, 644.7 refs.

Pinta in the Tepalcatepec Basin, Michoacan, Mexico. I. Field Identification of the Disease.

II. Mass Survey Considerations.

III. Survey Results and Interpretation.

IV. Serologic Findings in a Survey. Edmundson, W. F., Rico, A. L., and Olansky, S. (1953). Amer. J. Syph., 37, 201, 4 refs ; 207 ; 213, 7 refs ; 221, 3 figs, 3 refs.

Geographical and Ethnographical Venereology. (Geographisch-ethnographische Venereologie.) LÖHE, $H$. (1953). Derm. Wschr., 127, 433.7 figs, 28 refs.
Clinical Significance of the Presence of the Antibody against Treponemal Protein in Latent Syphilis. (II significato clinico sierologico della presenza dell 'anticorpo antitreponemico antiproteico (TL) nella sifilide latente.) Codeca, M. (1952). G. ital. Derm. Sif., 93, 510. 32 refs.

Patients with Negative Kahn Standard Tests and Reactive VDRL Slide Tests for Syphilis. OlanSKy, S., BowdoIN, C. D., Harris, A., and Rambo, D. S. (1953). Amer. J. Syph., 37, 134.2 refs.

Problems in the Diagnosis and Treatment of Syphilis. Thomas, E. W. (1953). J. Mich. med. Soc., 52, 854.

Trepone ma Pallida Immobilization Test in the Diagnosis of Syphilis. WheEler, A. H. (1953). J. Mich. med. Soc., 52, 859.19 refs.

Clinical and Serological Study of the Significance of the Presence of the Antiprotein Antibody Alone in the Serum in Latent-Syphilis. (Studio clinico e sierologico sul significato della presenza del solo anticorpo antiproteico (TL) nel siero del luetico latente.) OLIVETTI, L. (1953). G. ital. Derm. Sif., 94, 217.1 ref.

Arsenoxide Preparation for the Prevention of Transfusion Syphilis. (Über ein Arsenoxydpräparat zur Verhütung der Transfusions-Syphilis.) ScHMIDT, K. H. (1953). Z. Hyg. InfektKr., 137, 35. Bibl.

Clinical and Serological Experience in the Treatment of Syphilis with "Spirotrypan". (Klinisch-serologische Erfahrungen bei der Luesbehandlung mit "Spirotrypan ".) Thelen, K. (1953). Z. Haut- u. GeschlKr., 15, 126.2 figs, 14 refs.

Gumma of the Brain with Hypothalamic Symptoms. Raskin, N. (1953). Amer. J. Syph., 37, 156. 2 figs, 13 refs.

Progressive Bulbar Palsy due to Syphilis. Cook, R. E. (1953). Amer. J. Syph., 37, 161. 5 refs.

Syphilitic Poliomyelitis. (Poliomyelitis Luetica.) SPOTA, B., and PARvis, D. A. (1953). Pren. med. argent., 40, 518. 1 fig.

Syphilis of the Central Nervous System. (De la syphilis nerveuse.) Riser, LAVITRY, Gliezes, and Ribaut. (1953). Bull. Soc. méd. Hôp. Paris, 69, 69.

Variation of Electroencephalogram Patterns in a Case of Neurosyphilis. SeEley, L. J., and Dille, R. S. (1953). Dis. nerv. Syst., 14, 138. 3 figs, 7 refs.

Syphilitic Polyradiculoneuritis. (Un caso di poliracicolonevrite sifilitica.) URAS, A. (1953). Acta neurol. (Napoli), 8, 443.12 refs. 
Incidence of Involvement of the Central Nervous System in Endemic Syphilis in Anatolia. (Über die Häufigkeit der Syphilis des Zentralnervensystems bei Endemischer Syphilis in Anatolien.) MARCHIONINI, A. (1952). J. nerv. ment. Dis., 116, 1102.6 refs.

Cutaneous Lesions in Neurosyphilis ; Rapid Cure with Combined Intrathecal Treatment with Vaccine, Bismuth, and Iodine. (Lesioni cutanee in neuroluetico: guarigione rapida con associazione di vaccino, bismuto, iodo endorachide.) VENTRA, D. (1953). Acta neurol. (Napoli), 8, 369.4 figs, bibl.

Problem of Syphilitic Balanitis. (Le problème des balanites syphilitiques.) PAGĖs, F., and FreYria, J-L. (1953). Presse méd., 61, 665.30 refs.

Cardiovascular Syphilis in a General Medical Clinic. LuCIA, S. P., HARP, V. C., and Hunt, M. L. (1953). Publ. Hlth, 68, 405.

Studies in Cardiovascular Syphilis. III. The Natural History of Syphilitic Aortic Insufficiency. WEBSTER, B., Rich, C., Densen, P. M., Moore, J. E., Nicol, C. S., and Padget, P. (1953). Amer. J. Syph. 37, 301. 10 figs, 12 refs.

Luetic Osteomyelitis. A Case Report. Bailey, W. L. (1953). Delaware St. med. J., 25, 71. 2 figs, 6 refs.

Symmetrical Syphilis of the Clavicle. (Sifilis clavicular simetrica.) Maruri C. Aguilera, and Zorrilla, M. BrenA (1953). Act. dermosifiliogr. (Madr.), 44, 549. 5 figs, 11 refs.

Syphilis and the Muscles. (Lues und Muskel.) Stransky, E., and Teichmann, J. (1953). Wien. klin. Wschr., 29, 590.

Syphilitic Mediastinitis. Leather, H. M. (1953). Lancet, 265, 116. 5 figs, 4 refs.

Syphilis of the Bladder. (Sulla sifilide della vescica.) Benedetti-Valentini, S. (1953). Policlinico, Sez. prat., 60, 1116. 2 figs, 18 refs.

Syphilitic Parkinsonism. NeILl, K. G. (1953). Brit. med. J., 2, 320. 12 refs.

Tabes Dorsalis To-day. Reese, H. H. (1952). J. nerv. ment. Dis., 116, 1109.1 fig., 6 refs.

Problems in Syphilis. RedDY, D. J. (1953). Indian J. vener. Dis. 19, 58.6 refs.

Syphilitic Changes in the Fundus with particular reference to Latent Syphilis. (Veränderungen am Augenhintergrund bei Lues, mit besonderer Berücksichtigung der Lues latens.) Palich-Szántó, P. (1953). Klin. Mbl. Augenheilk., 123, 208. 5 figs, 1 table, 40 refs.

\section{SYPHILIS (Pathology)}

Pseudo-Syphilitic (Wassermann-Positive) Virus Pneumonia. (Die pseudo-luische (Wassermann-positive) Virus-pneumonie.) HerzoG, H., and Pulver, W. (1953). Schweiz. med. Wschr., 83, 227. 8 figs, 38 refs.

Between 1940 and 1952 the authors have observed 37 patients with pneumonia in whom the result of the Wassermann reaction was transiently positive. All but three of the patients had fever lasting 7 to 10 days, the illness beginning in most cases with general symptoms rather than those of respiratory tract infection. In two cases there were no symptoms at all, while in fifteen there were signs of diffuse bronchitis, in sixteen of pneumonia, and in the remaining four cases there were no abnormal signs in the lungs. The radiographic abnormalities consisted of ill-defined areas of mottling of various sizes, which usually disappeared in 3 to 5 weeks ; in four cases the hilar shadow was enlarged. The positive Wassermann reaction was usually obtained 3 to 4 weeks after the radiographic abnormalities had cleared up. The presence of cold agglutinins was not demonstrated. There were no abnormal physical signs in the nervous system, but of fifteen cases in which lumbar puncture was performed, in three some abnormality was found in the cerebrospinal fluid. The authors believe that in these cases the pneumonia was due to a virus. Similar cases have previously been reported as " pseudo-luetic perihilar bronchopneumonia" and "Wassermann-positive lung infiltrations".

[The cases described in this paper seem to differ from other cases of pneumonia only in having a transiently positive Wassermann reaction, but this has been recorded in many diverse febrile illnesses. There is no convincing evidence that the condition was due to a virus. To describe it as a new disease entity hardly seems justified, and may be misleading.]

J. R. Bignall

Production of Immobilizing Antibodies unaccompanied by Active Immunity to Treponema pallidum as shown by injecting Rabbits and Mice with the Killed Organisms. McLeod, C. P., and Magnuson, H. J. (1953). Amer. J. Syph., 37, 9. 15 refs.

A study was carried out at the U.S. School of Public Health, Chapel Hill, North Carolina, of the immunological response of rabbits and mice to killed inocula of the Nichols strain of Treponema pallidum. The results confirmed the findings of other investigators that the presence of reagin does not confer immunity in rabbits, and that the immunological response of the experimental host to injections of killed $T$. pallidum is influenced by :

(1) the method of killing the organisms,

(2) the number of organisms injected,

(3) the species of animal used, and possibly

(4) the duration of immunization.

Injections into rabbits of relatively small numbers of organisms killed by heat or by " mapharsen " (oxyphenarsine) caused an appreciable rise in the treponemal 
immobilizing (T.P.I.) titre, standard serum tests changing from negative to positive reactions. Control injections of heated or mapharsen-treated normal testicular tissue did not elicit these responses. Of thirteen rabbits tested twelve developed immobilizing antibody, and all of the thirteen developed reagin after inoculation with heatkilled treponemes. It was later possible to infect the " immunized" rabbits with an intracutaneous injection of 200 living organisms, although nine out of twelve surviving animals showed immobilizing antibody at the time of challenge.

Mice inoculated with $8 \times 10^{6}$ living $T$. pallidum did not develop immobilizing antibody or immunity to reinoculation within 3 months. When later 30 and 200 million heat-killed organisms were injected, although the T.P.I. titre rose, there was likewise no immunity to reinoculation.

G. L. M. McElligott

Meinicke (Kvittingen) and Mueller Ballung (Clotting) Tests in comparison with Standard Kahn and Cardiolipin (Kline) Tests. Schmid, E. E., and Velaudapillai, T. (1953). Ceylon J. med. Sci., 8, 157. 6 refs.

The authors, at the Medical Research Institute, Colombo, carried out a series of parallel tests on 15,057 specimens of serum with the Meinicke (Kvittingen), Mueller Ballung (clotting), Kahn, and cardiolipin (Kline) techniques. Exact clinical information was available for 2,560 specimens. The technique of the first two of these tests was slightly modified and is briefly described. It is pointed out that the Meinicke (Kvittingen) test requires only minimal apparatus and is carried out on noninactivated serum, and that under certain tropical conditions (for example, in Colombo) no moist chamber at $37^{\circ} \mathrm{C}$. is necessary. Further tests are being performed to determine an average threshold of atmospheric humidity permitting the moist chamber to be dispensed with. [Under European climatic conditions this is, however, an essential part of the technique.]

The results of the cardiolipin test showed the best agreement with the positive clinical diagnoses, but the test was less specific with non-syphilitic sera, whereas the Meinicke (Kvittingen) test gave the lowest percentage of false positive results. It is pointed out that the Mueller Ballung test takes a very long time (18 hours) at room temperature. The high temperature prevailing in Colombo tends to induce non-specific clotting, the room temperature of $17^{\circ} \mathrm{C}$. recommended for the preparation of the antigen being difficult to procure in the Tropics.

A paired comparison of percentage agreement was made, the best over-all agreement, and also that for positive sera, being obtained with a combination of the Kahn and cardiolipin tests ; for non-syphilitic sera the Kahn-Meinicke combination showed the highest agreement. Almost as good agreement was, however, found with combinations of the other tests; but as the combination cardiolipin-Meinicke is the most easily performed, it is recommended. The eminent suitability of the Meinicke (Kvittingen) test for field investigations is stressed.
Specificity Results of Kahn and Cardiolipin Tests in Recent Official Evaluations. KAHN, R. L., and McDermott, E. B. (1953). Univ. Mich. med. Bull., 19, 163. 6 refs.

Use of Some Synthetic Phosphatides in Antigens for the Serodiagnosis of Syphilis. Tonks, D. B., and Allen, R. H. (1953). Science, 118, 55.8 refs.

Observations based on Syphilis-Serologically studied Material with special reference to the Position of the Cardiolipin and Sitolipin Antigens in Syphilis Reactions and to the Incidence of Sero-positive Syphilis in Turkü and Pori County (Finland) and to the Incidence of Certain Diseases among Hospital Patients with Seropositive Syphilis (In English). KALLIOMÄKI, L. (1953). Ann. Med. exp. Biol. Fenn., 31, Suppl. 6. 4 figs, bibl.

Comparative Study with Cardiolipin Antigen of the Wassermann Reaction and the Kolmer Technique. (Vergleichende Luesuntersuchungen mit dem Cardiolipin-Antigen in der Wa.R.- und Kolmer-Technik.) GAASE, A. (1953). Z. Hyg. InfektKr., 137, 161. 9 refs.

Normal Limits in the Reversal of Serum Reactions after Treatment of Syphilis. (Die Grenzen des Normalen beim Rückgang der Seroreaktionen nach Luesbehandlung.) GAHLEN, W. (1953). Hautarzt, 4, 380. 2 figs, 13 refs.

Non-specific Reaction in the Serology of Syphilis. (Contributo allo studio delle reazioni aspecifiche nella sierologia della sifilide.) Pozzo, G. (1953). G. ital. Derm. Sif., 94, 173. 8 figs, 49 refs.

Effect on the Treponemal Antibodies and Lipoids of Patients with Neurosyphilis of Electric Convulsion Therapy. (Comportamento degli anticorpi treponemici e lipoidei in soggetti neuroluetici dopo applicazioni elettro-convulsivanti.) MENEGHINI, C. L., and Sanguineti, I. (1953). G. ital. Derm. Sif., 94, 205. 6 refs.

Serological Discrepancies in the Diagnosis of Syphilis. (Las discordancias serologicas en el serodiagnostico de la sifilis, papel que cabe atribuir al antigeno empleado en la practica de las reacciones.) Vilanova, X., and Catasus, J. M. (1953). Act. dermo-sifiliogr. (Madr.), 44, 543. 1 fig.

Effects of Certain Temperatures and Time Limits on the VDRL Slide Test. Cannefax, G. R., Beyer, H. R., and Johnwick, E. B. (1953). Amer. J. Syph., 37, 348. 1 fig., 8 refs.

Clarification of Syphilitic and Nonsyphilitic Serodiagnostic Reactions. KAHN, R. L. (1953). J. Amer. med. Ass., 152, 1204.3 figs, 12 refs. 
Specificity of the Luotest in Leprosy. Schmid, E. E., and Thillainathan, P. (1953). Ceylon J. med. Sci., 8, 171. 18 refs.

Attempt to Produce a Penicillin-Resistant Strain of Treponema Pallidum in Experimental Syphilis. Probey, T. F. (1953). Amer. J. Syph., 37, 369. 10 refs.

Search for Treponemes in Mice with Experimental Syphilis. HARD, S. (1953). Acta derm-venereol. (Stockh.), 33, 342.6 figs, bibl.

\section{SYPHILIS (Therapy)}

Placental Treatment of Tabetic Optic Atrophy. (Plazentabehandlung bei der tabischen Sehnervenatrophie.) FEIST, S. (1953). Klin. Mbl. Augenheilk., 123, 34. 4 figs, 36 refs.

The value of anti-syphilitic and malarial treatment of tabetic optic atrophy is doubtful. This treatment may even be dangerous. Better results are obtained by organic extracts which act as vasodilators and may also exercise a hormonal influence. The placenta contains four hormones : follicular, corpus luteum, chorionic, and the male hormone. All four are vasodilators, as are the tissue hormones of the placental histamine and choline. The hormone contents of the placenta are highest in the third and fourth month of pregnancy. No difference, however, could be found in the therapeutic effect of young or ripe placental tissue. Of ten cases treated, six were much improved, two only slightly, and two not at all.

H. Lytton

Haemorrhagic Encephalitis as a Complication during the Treatment of Interstitial Keratitis due to Congenital Syphilis. KiIANmies, L. (1953). Acta ophthal. (Kbh.), 31, 159.

Observations on a Series of 39 Cases of Erythrodermia due to Neoarsphenamine. (Unos comentarios con motivo de la observacion de 39 casos de eritrodermias novarsenobenzolicas.) Gregorio, E. de, and Cisneros, T. (1953). Act. dermo-sifiliogr. (Madr.), 44, 528. Bibl.

Treatment of Syphilis with Penicillin (Combinations of Procaine Penicillin and PAM). (Tratamiento de la sifilis con penicilina compuestos de procaina-penicilina y PAM.) Orbaneja, J. Gomez, Montero, J., and Perez, A. Garcia, (1953). Act. dermo-sifiliogr. (Madr.), 44, 499.20 refs.

Penicillin in the Treatment of Syphilis. (Penicilina en el tratamiento de la sifilis.) AzUA, L. de, MARron, J., and MAR, R. (1953). Act. dermo-sifiliogr. (Madr.), 44, 520. 9 refs.
Treatment of Early Syphilis with a Single Dose of Penicillin (PAM). (El tratamiento de la sifilis precoz con dosis unica de penicilina (PAM).) Vilanova, X. and Alvarado, L. (1953). Act. dermo-sifiliogr. (Madr.), 44, 509. 4 figs.

Preliminary Report on the Treatment of Early Syphilis with Depot Penicillin. (Primeros resultados del tratamiento de la sifilis precoz con penicilina retardada.) Prieto, J. Gay, Cascos, M. Alvarez, and Orusco, M. (1953). Act. dermo-sifiliogr. (Madr.), 44, 483. 5 figs.

Treatment of Early Syphilis with Penicillin. (Die Penicillinbehandlung der Frühsyphilis Bericht über fünfjährige Erfahrungen nebst einigen serologischen Bemerkungen.) FeLKE, J. (1953). Dtsch. med. Wschr., 78, 1295 . 8 refs.

Results of Treatment of Early Syphilis with a Single Injection of Procaine Penicillin $G$ in Oil and Aluminum Monostearate. Thomas, E. W., Rein, C. R., LANDY, S. E., and KITCHEN, D. K. (1953). Amer. J. Syph., 37, 374. 6 refs.

Penicillin in the Treatment of Neurosyphilis. (La penicilina en el tratamiento de la neurolues.) PEREYRA KÄFer, J., Poch, G. F., and CANTó, A. E. (1953). Pren. med. argent., 4i, 1465.

Treatment of Neurosyphilis with Penicillin. (Zur Behand lung der Neuro-Lues mit Penicillin.) Dammann H. J., and SchmidT, E. (1953). Dtsch. med. Wschr. 78, 1231. 2 figs, 31 refs.

Treatment of Neurosyphilis with "Spirotrypan". (Behandlung mataleutischer Erkrankungen mit "Spirotrypan".) Brobell, A., and HÄrTER, O. Med. Klin., 48, 928.10 refs.

Absorption and Excretion of "Spirotrypan", a New Antisyphilitic Drug of the Arsenobenzol Group. (Über Resorption und Ausscheidung von "Spirotrypan" einem neuen Antiluicum der Arsenobenzolreihe.) Herrmann, W., and Ther, L. (1953). Arch. Derm. Syph. (Berl.), 195, 670. 7 figs, 24 refs.

\section{GONORRHOEA (General)}

Comparative Use of Silver Nitrate and Penicillin in the Eyes of the Newborn. Mallek, H., SPOHN, P., and MalleK, J. (1953). Canad. med. Ass. J. 68, 117. 8 refs.

With the object of determining whether penicillin can replace silver nitrate as a prophylactic against conjunctivitis in the newborn, the authors applied penicillin ointment and silver nitrate during alternate months to the eyes of all newborn infants at St. Paul's Hospital, Vancouver. Penicillin ointment, 2,500 units per ml., in a base which was insoluble in water, was instilled into the conjunctival sac of each eye three times a day for 
three days, beginning immediately after birth. In a second series of cases 100,000 units of penicillin per $\mathrm{ml}$. was instilled in one application immediately after birth. All the infants were observed during their stay in hospital for evidence of redness in the eye, lacrimation, purulent discharge, or swelling of the lids. One month after birth and two months post partum a questionary was sent to all mothers.

None of the infants who had penicillin or silver nitrate required treatment for ocular infection. In those treated with silver nitrate an immediate chemical reaction was observed, with swelling of the eyelids, redness, and discharge. Similar signs of irritation were seen in the infants receiving several applications of penicillin ointment, and this was attributed to repeated manipulation of the eyelids, since none of the infants receiving a large single application of penicillin ointment showed any signs of irritation. All the infants in a control group treated with an ointment which did not contain penicillin developed conjunctivitis. The questionary revealed slightly fewer complaints from the mothers of the penicillintreated infants than from the mothers of infants treated with silver nitrate.

C. McCulloch

Preliminary Report on Prophylaxis of Ophthalmia Neonatorum. Cousineau, G. G., and Lloyd, L. A. (1952). Trans. Canad. ophthal. Soc., 5, 75. 4 tables, 6 refs.

A group of 1,703 newborn infants received Sulmefrin (Sulmefrin Ophthalmic, Squibb) at birth; a second group of 1,127 infants received sodium sulphacetamide ointment (Schering); a third group of 1,175 infants received silver nitrate 1 per cent.; and fourth group of 640 infants received, alternate cases, 1 per cent. silver nitrate and 10 per cent. sodium sulphacetamide.

In the entire series of 4,326 infants there were only three cases of gonorrhoeal ophthalmia. Modern methods of prenatal care are probably more important than any prophylactic preparation in decreasing this incidence. Inclusion conjunctivitis occurred in 7 per cent. of infected eyes from the group treated with sulpha preparations but in only 1 per cent of infected eyes in the group treated with silver nitrate. The incidence of chemical reactions with silver nitrate exceeds the incidence of conjunctival infection, while with sulpha preparations chemical reactions are negligible.

C. McCulloch

Prophylaxis of Gonorrhoeal Conjunctivitis with Penicillin in 4,528 Cases. (Bericht über Augenprophylaxe mit Penicillin in 4,528 Fällen.) BERWIND, T. (1952). Münch. med. Wschr., 94, 2015.

Report on the prophylactic use of penicillin in water solution $(10,000 \mathrm{u}$. in $3 \mathrm{ml}$. water) in 4,528 newborn children, instead of Credé's prophylaxis. The incidence of non-specific conjunctivitis was decreased from 11.01 per cent. to 2.53 per cent. W. Leydhecker

Epidemic Gonococcal Conjunctivitis in Algeria. Cases collected in the Southern Territories. (La conjonctivite gonococcique épidémique en Algérie. A propos d'ob- servations recueillies dans les Territories du Sud.) Hugonot, R. (1952). Rev. Cps Santé mil., 8, 363.

\section{GONORRHOEA (Therapy)}

Chloromycetin Treatment of Gonorrhea. Evaluation of a Single Oral Dose administered to Patients with Acute Gonorrheal Urethritis. BARRETT, C. D., and Burton, M. E. (1953). Amer. J. Syph., 37, 165. 10 refs.

Although several previous reports on the treatment of gonorrhoea with chloramphenicol have indicated the effectiveness of relatively small total doses ranging from 0.75 to $6 \mathrm{~g}$., Greaves and others (J. vener. Dis. Inform., $1950,31,261$ ) claim to have obtained satisfactory results with a single oral dose as small as $0.75 \mathrm{~g}$. In view of this finding, the present authors, in an investigation at the Venereal Disease Clinic of the Health Department of Detroit, Michigan, set out to evaluate the effectiveness of a single oral dose of chloramphenicol in the treatment of gonorrhoea, comparing their results with those obtained from the administration of penicillin.

A total of 1,718 males suffering from acute gonorrhoeal urethritis was divided into two groups of 904 and 814 patients respectively. In the first group 460 patients were given a single oral dose of $1 \mathrm{~g}$. chloramphenicol and 44 received penicillin; in the second group, 409 patients were given $2 \mathrm{~g}$. chloramphenicol in a single oral dose and 405 received penicillin. The penicillin treatment in each case consisted of a single intramuscular injection of 300,000 units procaine penicillin in oil with aluminium monostearate. Patients were examined $1,2,3,7$, and 15 weeks after treatment, but the difficulty of deciding " reinfection" or "failure" at 7 days prompted the authors to carry out the first post-treatment examination after 2 days in the later cases under review.

Between 50 and 60 per cent of patients in each group reported for follow-up examination. At the end of one week negative urethral cultures were found in 88.7 per cent. of patients receiving $1 \mathrm{~g}$. chloramphenicol and in 93.3 per cent. of those receiving $2 \mathrm{~g}$., whereas in the penicillin-treated series the figures were $97 \cdot 4$ per cent. and 96.6 per cent. respectively. In this connexion the authors stress the importance of cultural as against purely clinical evaluation of results.

No serious side-reactions occurred in any of the groups, though some patients complained of mild gastroenteritis, dizziness, or " bad taste". The risk of the development of aplastic anaemia after repeated or indiscriminate administration of chloramphenicol is stressed. In instances of undoubted reinfection, cure was obtained by re-administering the same drug, suggesting that the gonococci were not resistant to the particular drug used in these cases.

The authors conclude that while penicillin remains the drug of choice in the treatment of acute gonorrhoea, the nearly similar results obtained with oral administration of $2 \mathrm{~g}$. chloramphenicol suggest that this drug may be substituted for penicillin when the latter is not available or is contraindicated.
Douglas J. Campbell 
Treatment of Acute Gonococcal Urethritis in the Male with Chloramphenicol (Chloromycetin). Daruvala, B. A. (1953). Indian J. vener. Dis., 19, 63.

Does the Penicillin Sensitivity of Gonococci Vary ? (̈̈ndert sich die Penicillinempfindlichkeit der Gonokokken ?) Schreus, H. T., SchüMmer, H., Gahlen, W., and JAECKEL, A. (1953). Z. Haut-u. GeschlKr., 16, 373. 1 fig., 9 refs.

\section{CHEMOTHERAPY}

Intramuscular Chloromycetin (Chloramphenicol) in the Treatment of Venereal Disease. Olansky, S., HaRb, F. W., Wood, C. E., and RAMbo, D. S. (1953). Amer. J. Syph., 37, 253.11 refs.

Aureomycin in the Treatment of Granuloma Inguinale. Krishnamurthi, M. V., SobHanAdRI, C., and SoWmini, C. N. (1953). J. Indian med. Ass., 22, 402.8 refs.

Comparison of Terramycin, Streptomycin, and Penicillin in the Abortive Treatment of Non-Specific Urethritis. Willcox, R. R. (1953). Amer. J. Syph., 37, 383. 2 refs.

Reiter's Syndrome treated with Aureomycin. (Sindrome de Reiter tratado con aureomicina.) SCHERSCHEINER, J., Lockhart, J., Oehninger, C., and Guerrebere, A. (1952). Arch. urug. med., 40, 133. 35 refs.

Susceptibilities of Kazan, Nichols, and Reiter Strains of Treponema and Pleuropneumonia-like Organisms to the Antibiotic Erythromycin (Ilotycin). KELLER, R., and Morton, H. E. (1953). Amer. J. Syph., 37, 379. 17 refs.

\section{OTHER VENEREAL DISEASE CONDITIONS}

ACTH in Reiter's Syndrome. Four Cases, with Review of the Literature. LARSON, E., and ZOECKLER, S. J. (1953). Amer. J. Med., 14, 307. 5 figs, 33 refs.

To the three cases of Reiter's syndrome treated with ACTH already reported in the literature the authors add four more which were seen at the Veterans Administration Hospital, Des Moines, Iowa.

The first patient, a man of 24 , had a severe attack of Reiter's syndrome which did not respond to administration of salicylates, penicillin, streptomycin, or a nonspecific protein; he resisted physiotherapy because of pain and stiffness in the joints. After a course of ACTH in doses of $25 \mathrm{mg}$. every 6 hours, the patient was able to walk, his appetite and general condition improved, and physiotherapy could be carried out satisfactorily. Hospital treatment in this case lasted 7 months.

The second patient had an even more severe attack of Reiter's syndrome, which required 15 months' hospital treatment. The authors believe that had it not been for the administration of ACTH physiotherapy in this case would have been impossible and the residual deformity would have been severe.

The third patient, who had the most severe attack of Reiter's syndrome, became refractory to ACTH, and marked osteoporosis developed. Physiotherapy, although painful, was persisted in, as was administration of ACTH, and the patient recovered completely, the duration of treatment having been 17 months.

The fourth patient, who had a less severe attack than the others had had a short course of cortisone, with temporary relief of symptoms, before admission to hospital. Arthritis recurred and he was admitted to hospital, where administration of ACTH permitted physiotherapy to be maintained until all joint distress had disappeared.

The authors conclude that ACTH has a definite place in the management of Reiter's syndrome.

James D. P. Graham

Trichomonas vaginalis in the Male. The Experimental Infection of a Few Volunteers. LANCELEY, F., and McEntegart, M. G. (1953). Lancet, 1, 668. 17 refs.

The authors describe the results of urethral inoculation of a pure culture of Trichomonas vaginalis in five male volunteers at St. Luke's Clinic, Manchester ; five other male volunteers receiving an inoculation of a sterile culture medium served as controls. A strain of $T$. vaginalis, isolated 4 months previously from a patient with vaginitis, was maintained in bacteria-free culture in a modified cysteine-peptone-liver-maltose medium which consistently grew $2,000,000$ protozoa per $\mathrm{ml}$. after 24 hours' incubation, this count being confirmed for the culture used to infect the volunteers. After the subjects has passed urine, $2 \mathrm{ml}$. of the inoculum was instilled by means of a warm pipette about $1 \frac{1}{2}$ inches $(3.75 \mathrm{~cm}$.) into the urethra. The subjects were examined at 7 a.m. and 11 a.m. each day for the first 10 days and thereafter at longer intervals. The 7-a.m. urine was centrifuged and examined for trichomonads, and at 11 a.m. scrapings from inside the urethra were also tested ; sometimes even when there was a urethral discharge, these scrapings provided the only evidence of the presence of $T$. vaginalis.

No abnormality was observed in the controls. All five of the infected subjects had a mild transient urethritis in the first 24 hours, but no trichomonads were recovered. The presence of the organism was, however, demonstrated in three of these five infected subjects from the 6th to 9th days after inoculation, the urethritis having become moderately severe. The authors suggest, therefore, that in all patients with non-specific urethritis an investigation for the presence of $T$. vaginalis should be carried out several times over a period of 7 to 10 days from the probable date of infection. The protozoa persisted for 44 to 94 days in two patients who developed a mild prostatitis, but examination of serum from these patients failed to reveal antibody to the protozoa. T. Anwyl-Davies 
Relationship between Reiter's Syndrome and Gonorrhoea, reflected in some Cutaneous Symptoms. (In Swedish.) RuikKa, I. (1953). Nord. Med., 50, 976. 33 refs.

Report of a case of atypical Reiter's syndrome in a female with conjunctivitis and keratoderma. The pathogenic relationship to gonococcal infection is discussed.

E. Godtfredsen

A Study of 23 Cases of Reiter's Syndrome. HALl, W. H., and Finegold, S. (1953). Ann. int. Med., 38, 533.

In the 23 cases reported, ocular involvement was restricted in the main to a mild or moderate bilateral conjunctivitis. The authors present evidence which suggests that the disease may be due to a venereal infection.

J. R. Hudson

Reiter's Disease. (La malattia di Reiter.) BELLIS, U. DE (1952). Pediatria (Napoli), 60, 339. 33 refs.

Rist-Reiter-Fiessinger Syndrome. (La sindrome di RistReiter-Fiessinger.) Persico, L. (1952). Rass. med. (Milano), 29, 126.

Oculo-Urethro-Arthritis or Reiter's Disease. (La malattia artro-oculo-uretrale o malattia di Reiter.) ERCOLI, G. (1952). Rass. Fisiopat. clin. ter., 24, 311.

Granuloma Venereum (also called " Granuloma Inguinale ," and "Ulcerating Granuloma of the Genitalia"). KAPUR, T. R. (1953). Indian J. vener. Dis., 19, 74. 2 refs.

Recent Studies on Non-Specific Urethritis. WAGNER, B. M., Morse, W. H., and Kuhns, D. M. (1953). Amer. J. publ. Hlth, 43, 853. 21 refs.

\section{PUBLIC HEALTH}

Mass Treatment of Treponemal Diseases, with Particular Reference to Syphilis and Yaws. Guthe, T., REYNOLDS, F. W., KraG, P., and Willcox, R. R. (1953). Brit. med. J., 1, 594.3 figs, 24 refs.

This paper gives an account of one of the activities of the World Health Organization (W.H.O.) in the investigation of a group of diseases due to infection with closely related treponemes, the acute and chronic pathological conditions caused by which result in incapacitation and invalidism on such a scale as to be of considerable social and economic importance. In addition to syphilis, which is widely spread throughout the world, there are a number of important geographical "pockets" of treponemal infection, such as the "endemic syphilis" of Bosnia, Yugoslavia, Madras, Bechuanaland, and Tahiti, " njovera" of Southern Rhodesia, "bejel" (a non-venereal treponemal infection of children in the Eastern Mediterranean area), and yaws and pinta, which are confined to tropical and semi-tropical regions. Unfortunately in all these areas facilities for serodiagnosis are extremely inadequate and likely to remain so. Under projects organized by W.H.O. during a period of less than 3 years, 9,000,000 persons have been examined and over 3,000,000 treated with penicillin, which is the most efficient and safest therapeutic agent for all the treponematoses. Successful treatment has been found to depend on the maintenance of an effective plasma level of penicillin for an adequate period. For this purpose the most economical method of treatment is to give 1 to 2 mega units procaine benzylpenicillin in oil with 2 per cent. aluminium monostearate (P.A.M.), repeated if possible after an interval of 3 to 5 days. The need for the proper standardization of P.A.M. is stressed and the minimum specifications established by W.H.O. are described.

There appears to be ample evidence that mass treatment of clinically diagnosed treponemal disease in the early stages alone will not suffice to stamp out the disease and that there must also be supplementary long-term measures if such projects are to succeed. There also seems to be a strong case for the " preventive " or " abortive" treatment of contacts, but on this point medical opinions differ. In general it is concluded that results will be far from satisfactory unless 90 per cent. of a population are examined and unless re-checking is carried out after an interval of 6 to 12 months. [It is doubtful whether this could ever be achieved without a far greater degree of cooperation of the population concerned than has yet been obtained.]

Neville Mascall

[The above article should be read in conjunction with a previous paper by two of the authors (Reynolds and Guthe, Amer. J. Syph., 1952, 36, 424 ; Abstracts of World Medicine, 1953, 13, 114), which covers much the same ground.-EDITOR]

Community Organization for Mass Testing Programmes. Mason, W. A. (1953). Amer. J. Syph., 37, 362. 9 refs.

Variations in the Stability of Sexual Relations as Explanation of Differences in the Spread of Syphilis and Gonorrhea. MARCUSSEN, P. V. (1953). Amer. J. Syph., 37, 355. 1 fig., 18 refs.

The Venereal Diseases-A Vanishing Problem ? Cowan, J. A., and Shaw, W. D. (1953). J. Mich. med. Soc., 52, 845 and 886.1 fig., 3 refs.

Half a Century of International Control of the Venereal Diseases. Bauer, T. J. (1953). Publ. Hlth Rep. (Wash.), 68, 779.5 figs, 22 refs.

Medico-Social and Medico-Sociological Control of Venereal Disease. FreEd, L. F. (1953). S. Afr. med. J., 27, 686.23 refs. 


\section{MISCELLANEOUS}

Cat-Scratch Disease and Parinaud's Oculoglandular Syndrome. Cassady, J. V., and Culbertson, C. S. (1953). Arch. Ophthal. (Chicago), 50, 68. 3 figs, 28 refs.

Four cases of the oculo-glandular syndrome are reported which gave positive tests with the antigen of cat-scratch disease (probably a virus infection).

$$
\text { P. D. Trevor-Roper }
$$

Differences between Oral and Genital Strains of Human Pleuropneumonia-like Organisms. DIENES, L., and Madoff, S. (1953). Proc. Soc. exp. Biol. (N.Y.), 82, 36. 1 fig., 7 refs.

Pelvo-Spondylitis Ossificans in the Male and GenitoUrinary Infection. (In English.) ROMANUs, R. (1953). Acta med. scand. Suppl. 280, 1. 7 figs, bibl.
Therapy of Experimental Psittacosis and Lymphogranuloma Venereum (Inguinale) II. Activity of Quinoxaline-1 : 4-Dioxide and Substituted and Related Compounds, with a Note on the Morphological Changes induced in Lymphogranuloma Virus by these Compounds and by Antibiotics. HURST, E. W., LANDQUIST, J. K., Melvin, P., Peters, J. M., Senior, N., SilK, J. A., and Stacey, G. J. (1953). Brit. J. Pharmacol., 8, 297. 2 figs, 16 refs.

Squamous Cell Carcinoma of the Vulva Secondary to Granuloma Inguinale. AleXANDER, L. J., and SHIELDS, T. L. (1953). Arch. Derm. Syph. (Chicago), 67, 395. 5 figs, 5 refs.

Modern Trends in Diagnosis and Treatment of Venereal Diseases. KRISHNAMURTHI, M. V. (1953). Indian J. vener. Dis., 19, 49.29 rifs. 